\title{
ZALEW IRRACJONALNOŚCI? NIEKONIECZNIE \\ O zaufaniu do nauki i jej autorytecie rozmawiaja Łukasz Afeltowicz i Piotr Urbanowicz
}

\begin{abstract}
Abstrakt: Statements about the crisis of trust of citizens to science are common in the public and popular science discourse. Examples of anti-vaccination movements and climate change deniers are often used in reference to that statements. Nevertheless, there are strong indications that we don't encounter an irrationality glut. Conspiracy theories and pseudoscience have long history, just as irrational attitudes. Our irrationality is not unpredictable. Difficulties in acquirement of scientific knowledge could be predicted and categorized. Traditional education and simple refuting conspiracy theories proved to be unfortunate. In return, we should pay attention to remarkable approaches which enable "smuggling" the scientific knowledge and increasing the interest of layman in science.
\end{abstract}

Keywords: crisis of trust to science, pseudoscience, conspiracy theories, anti-vaccination movements, climate change.

Łukasz Afeltowicz - filozoficznie przeszkolony socjolog, związany z Instytutem Socjologii UMK od 2012 roku. Para się problematyką nauki i technologii. Sięga również do badań z zakresu socjologii ekonomicznej, filozofii nauki, kognitywistyki oraz participatory action research. Jest autorem prac poświęconych zagadnieniu instytucjonalnej, poznawczej i inżynieryjnej efektywności nauki (książki Laboratoria $w$ działaniu oraz Modele, artefakty, kolektywy). Wraz z Krzysztofem Pietrowiczem napisał Maszyny społeczne. W 2015 roku ukazała się książka Arystokraci i rzemieślnicy autorstwa jego i Radosława Sojaka. Aktualnie realizuje projekt badawczy w ramach NPRH poświęcony epidemiom chorób zakaźnych: ich publicznemu odbiorowi, czynnikom determinującym społeczne reakcje, wreszcie innowacjom społecznym, które mogą ograniczać negatywny wpływ czynników zakaźnych na populacje. W 2017 roku rozpoczął pracę w zespole badawczym powołanym w ramach projektu „Dzielnice innowacji? Przemysły kreatywne a przemiany miejskie” NCN Sonata BIS.

Piotr Urbanowicz: O instytucji nauki można mówić w wielu kontekstach. Ja chciałbym zaproponować panu refleksję na temat jej społecznego odbioru. Na szczególną uwagę może zasługiwać problem, jakim zajął się Bruno Latour w książce An Inquiry 
into Modes of Existence: An Anthropology of the Moderns ${ }^{1}$. Z ust akademików często słyszymy, że ,jeżeli ludzie nie będą ufać nauce, popadniemy w poważne tarapaty". Według Latoura jest to argument niewystarczający, a ponadto odsłania kruchość instytucji nauki, która nie znajduje przekonującej odpowiedzi dla kryzysu jej legitymizacji. O takim kryzysie legitymizacji, który zdefiniował Jürgen Habermas ${ }^{2}$, możemy mówić w obliczu teorii spiskowych, pseudonauk i debat na temat funkcji szczepionek czy globalnego ocieplenia. Jak pana zdaniem przedstawia się problem z legitymizacją nauki? Czy dotyczy on jej szczególnych praktyk, problemów strukturalnych, komunikacji społecznej czy filozoficznego umotywowania?

Łukasz Afeltowicz: Trudno mi się ustosunkować do tego pytania, gdyż nie znajduję danych z badań opinii potwierdzających to, że nastąpił gwałtowny spadek zaufania do nauki ${ }^{3}$. Najlepiej jednak patrzeć nie po opiniach, lecz po czynach lub - jak powiedziałby socjolog - praktykach społecznych. Przykładowo, przesłanką do tego, by mówić o kryzysie demokracji nie są opinie obywateli lub publicystów, czy też spadek zaufania do wybranych zawodów, ale fakt, że kolejne wybory polityczne w różnych państwach demokratycznych wygrywają ugrupowania, którym coraz trudniej uzyskać większość wyborczą, a utworzone w ten sposób rządy coraz szybciej tracą poparcie swoich wyborców, co coraz częściej wymusza rekonstrukcje lub przedwczesne wybory.

Pomiar legitymizacji politycznej wydaje mi się jednak zagadnieniem dużo łatwiejszym (bo już zestandaryzowanym) niż pomiar legitymizacji nauki. Poza tym naukowców nie wybieramy. Dlatego, idąc we wskazanym w pana pytaniu kierunku, skupię się na konkretnych przejawach załamania zaufania wobec nauki. Pseudonauki i teorie spiskowe są zjawiskami społecznymi znanymi od dawna. Weźmy proste przykłady z ubiegłego wieku: wciąż ciesząca się popularnością astrologia, Trójkąt Bermudzki, rozwój praktyk spirytualistycznych po I wojnie światowej, kwestionowanie lądowania misji Apollo na Księżycu, teorie głoszące, że HIV/AIDS opracowało lub szerzyło CIA etc. Nowością być może jest to, że osoby angażujące się w formy kon-

B. Latour, An Inquiry into Modes of Existence: An Anthropology of the Moderns, przel. C. Porter, Harvard University Press, Cambridge, MA-London 2013.

2 J. Habermas, Legitimation Crisis, przeł. T. McCarthy, Polity Press, Cambridge 2015.

3 Istnieją badania pokazujące, że w Stanach Zjednoczonych obywatele o poglądach konserwatywnych przejawiają niższy poziom zaufania do nauki niż osoby o poglądach liberalnych (G. Gauchat, Politicization of Science in the Public Sphere, „American Sociological Review” 2012, t. 77, nr 2, s. 167-187). Jednak nie mamy tu do czynienia z tąpnięciem. Spadek zaufania w tej grupie następował stopniowo od lat 70. ubiegłego wieku. Co ważne, różnica w poziomie zaufania jest niezależna od poziomu wykształcenia obywateli. Pogłębiająca się różnica ma charakter polityczny i zjawisko to przypuszczalnie będzie się nasilało w związku z obecnie obserwowaną polaryzacją dyskursu publicznego i sceny politycznej. Generalnie jednak poziom zaufania do nauki wśród Amerykanów utrzymuje się na stałym poziomie. Niemniej w sytuacji, gdy do władzy dochodzą ugrupowania konserwatywne, postawy kwestionujące twierdzenia naukowe mogą częściej pojawiać się w przekazie medialnym. Czym innym jest jednak widoczność tego typu postaw w mediach, a czym innym faktyczny poziom zaufania ludzi do nauki. 
testacji nauki typu ruch antyszczepionkowy rekrutują się coraz częściej z szeregów dobrze wykształconej klasy średniej, a nie z marginesów lub dołów społecznych. Pytanie: dlaczego?

Można by powoływać się na rozliczne kontrowersje, które potencjalnie podkopują zaufanie do nauki (np. kontrowersje wokół testów farmaceutycznych, podtrzymywane celowo kontrowersje wokół badań na temat związku palenia papierosów z rakiem, co miało na celu ochronę przemysłu tytoniowego $0^{4}$ ), kumulację różnych katastrof, za które część odpowiedzialności można przypisać naukowcom, wyczerpanie się jednostronnego modelu komunikacji wiedzy typu „nauka mówi - człowiek słucha”, przejście od komunikowania masowego do komunikacji w ramach odizolowanych baniek filtrujących ${ }^{6}$ doby mediów 2.0... Listę można by ciągnąć, ale problem z tego typu wyjaśnieniami jest taki, że mają one charakter ex post. Wiemy, że x, więc dopisujemy historię thumaczącą jak doszło do x. To, którą narrację wybierzemy, zależałoby od naszych osobistych preferencji, otoczenia społecznego lub kulturowego, w którym funkcjonujemy, ewentualnie innych, trudnych do przewidzenia czynników.

Na szczęście niektóre przejawy sprzeciwu wobec nauki dają się wyjaśnić prościej, bez tego typu dużych narracji. Czasami wystarczy odwołać się do pewnych typowych dla ludzkiego umysłu deficytów poznawczych, które mogą skutkować pojawianiem się równolegle jednakowych błędów w interpretacji doświadczeń i komunikatów ${ }^{7}$.

Sytuacja z naszym stosunkiem do szczepionek jest dobrym przykładem. Wiele osób obawiających się szczepień nie ma nic przeciwko antybiotykom, gdy tymczasem standardowe szczepienia są wysoce bezpieczne i skuteczne, a skuteczność antybiotyków jest niższa i wciąż maleje. Jednak, z perspektywy laika po szczepionce nie poczujemy się lepiej, a co najwyżej gorzej, ewentualna korzyść jest odwleczona w czasie, podczas gdy antybiotyk odczuwalnie zadziała od razu po zażyciu. Takie rozumowania heurystyczne, przydatne w wielu innych sytuacjach, wydają się dość dobrym podglebiem dla rozwoju ruchu antyszczepionkowego ${ }^{8}$.

4 D. Michaels, Manufactured Uncertainty, „Annals of the New York Academy of Sciences” 2006, t. 1076, nr 1, s. 149-162.

5 P. Stankiewicz, Od przekonywania do współdecydowania. Zarzadzanie konfliktami wokót ryzyka i technologii, „Studia Socjologiczne” 2011, nr 4 (203), s. 95-119.

6 E. Pariser, The Filter Bubble: How the New Personalized Web Is Changing What We Read and How We Think, Penguin Books, London 2012.

7 Bardzo ciekawym przykładem tego, jak bezpodstawne (i bardzo często szkodliwe) poglądy i twierdzenia mogą pojawiać się niezależnie w różnych kręgach kulturowych, instytucjonalizować się i trwać przez długi czas, jest przekonanie o korzyściach płynących z puszczania krwi. Zob. H. Miton, N. Claidière, H. Mercier, Universal Cognitive Mechanisms Explain the Cultural Success of Bloodletting, ,Evolution and Human Behavior” 2015, t. 36, nr 4, s. 303-312.

8 Należy również podkreślić, że szczepienia mają zapobiegać chorobom, które nie występują w populacji (tak długo, jak się szczepimy), co sprawia, że zagrożenie epidemiologiczne może być bagatelizowane, a niekiedy mitologizowane. Z kolei antybiotyki mają za zadanie zwalczyć zagrożenie, którego doświadczamy tu i teraz. 
W podobny sposób można podejść do sceptycyzmu/sprzeciwu względem tezy o wywołanej przez ludzką działalność zmianie klimatycznej. Zacznę od pewnego osobistego doświadczenia: w latach 90 . byłem uczony w szkole o zagrożeniach ekologicznych, w tym o dziurze ozonowej oraz efekcie szklarniowym, jak zwykło się było dawniej określać efekt cieplarniany. Oba zjawiska pamiętam jako porównywalnie groźne, choć koncepcja dziury ozonowej wydawała się bardziej czytelna. Nikt nie wyjaśnił w podręczniku, że drugie zjawisko jest wielokrotnie groźniejsze w swych następstwach. Obecnie z dziurą ozonową radzimy sobie dobrze, gdyż jest to zjawisko proste: zasadniczo wystarczył zakaz wykorzystania określonych substancji. Globalne ocieplenie to zjawisko wyjątkowo złożone. W przeciwieństwie do dziury ozonowej nie ma tu prostej, łatwej do zapamiętania metaforyki (np. dziura, przez którą coś się przedostaje; dziurę trzeba zalepić lub pozwolić się jej zrosnąć) ${ }^{9}$. Ludzie nie widzą bezpośredniego związku wzrostu temperatury z anomaliami pogodowymi czy blaknięciem raf koralowych. Naszemu umysłowi ciężko również pojąć koncepcję średniej temperatur, a to jej wzrostu powinniśmy się obawiać: przy dużych amplitudach rocznych trudno zrozumieć, jakie znacznie ma wzrost średniej temperatury o ułamek stopnia. Efektem tego rodzaju ograniczeń poznawczych są powszechne memy internetowe komentujące globalne ocieplenie zdjęciami zim stulecia, których autorzy pozostają nieświadomi, że załączone fotografie należałoby raczej traktować jako potwierdzenie tezy o globalnym ociepleniu niż jej zaprzeczenie ${ }^{10}$. Osobną kwestią jest to, że poznawcze ograniczenia naszego umysłu próbują wykorzystać grupy interesu kwestionujące zmianę klimatyczną.

Chciałbym uniknąć nieporozumienia. Ze stwierdzenia, że umysł ludzki w pewien typowy i przewidywalny sposób błądzi, nie należy wnioskować, że ludzie są głupi. Głupotą jest dopiero lekceważenie faktu, że w pewnych aspektach jesteśmy (przewidywalnie) irracjonalni ${ }^{11}$.

PU: W perspektywie Ulricha Becka, twórcy pojęcia „,społeczeństwo ryzyka”"12, nauka niejako znika w laboratoriach, oddzielając się od społeczeństwa, które musi brać na

9 S. Ungar, Global Warming versus Ozone Depletion: Failure and Success in North America, „Climate Research" 2003, t. 23, s. 263-274.

10 Od dłuższego czasu w dyskursie publicznym fraza „globalne ocieplenie” jest zastępowana przez określenie „zmiana klimatyczna”. Zabieg ten nie wydaje się przypadkowy. Słowo „ocieplenie” może sugerować, że powinniśmy się spodziewać gorętszych lat i łagodniejszych zim. Oczywiście ocieplenie klimatu to zjawisko dostrzegalne po uśrednieniu globalnych temperatur z kilkudziesięciu ostatnich lat. Co więcej, problematyczny jest nie tyle sam wzrost temperatury, ile jego następstwa, w tym nasilanie się ekstremalnych i nieprzewidywalnych zjawisk pogodowych (do których mogą zaliczać się wyjątkowo ciężkie zimy). Termin „zmiana klimatyczna” wydaje się bardziej ogólny, gdyż obejmuje całokształt zmian.

11 D. Ariely, Potęga irracjonalności. Ukryte sity, które wplywają na nasze decyzje, przeł. T. Grzegorzewska, P. Grzegorzewski, A. Nowak-Młynikowska, Smak Słowa, Sopot 2018.

12 U. Beck, Spoleczeństwo ryzyka. W drodze do innej rzeczywistości, przeł. S. Cieśla, Wydawnictwo Naukowe Scholar, Warszawa 2002. 
wiarę to, że naukowcy dbają o ich interes; nie pewność, lecz kategoria ryzyka zaczyna decydować o bezpieczeństwie. Czy zgadza się pan z taką tezą? Czy według pana może rodzić to pewne napięcie w budowaniu zaufania do nauki?

ŁA: Gdyby nauka nie „znikała” w laboratoriach, to automatycznie podkopałoby to jej autorytet społeczny oraz skuteczność technologiczną. Tak przynajmniej sugerują badania antropologów nauki i socjologów wiedzy naukowej, na których bezpośrednio powołuje się sam Beck. Dobrze oddaje to Bruno Latour, posługując się porównaniem polityka i naukowca ${ }^{13}$. Pierwszy zawodzi i jest niepewny w swych działaniach, bo musi radzić sobie $\mathrm{z}$ bieżącymi sytuacjami: zawsze ma tylko jedno podejście i oceniany jest na podstawie swoich ostatnich dokonań. Naukowiec z kolei może w czeluściach swojej pracowni popełnić wszystkie możliwe błędy, wyciągnąć z nich wnioski i upublicznić wyniki wtedy, gdy będzie miał już poczucie relatywnej pewności. Wystarczy jednak poprosić naukowca, by wypowiedział się o jakimś nowym zjawisku, które teoretycznie zalicza się do jego dziedziny, ale nie zostało jeszcze sprowadzone do pracowni naukowej i ,zredukowane”, a zobaczymy profesjonalistę zmuszonego do spekulacji, przyznania się do własnej ignorancji lub do proszenia o więcej czasu i środków na badania. Przykładowo, gdy społeczeństwa europejskie zostały wzięte z zaskoczenia przez chorobę szalonych krów, naukowcy pytani o naturę zagrożenia przez zaniepokojonych polityków odpowiadali: „Nie wiemy”: nie wiedzieli, jak działa mechanizm choroby i co za nią odpowiada.

Fakt, że nauka buduje swój autorytet, wykorzystując nieprzejrzystość laboratoriów, nie musi wzbudzać napięć. Wszak zaciekawionych interesariuszy zawsze można zaprosić do pracowni, oprowadzić ich po niej, ewentualnie zaprezentować kulisy pracy naukowej w trybie programu edukacyjnego lub popularyzującego naukę. Należy jednak przypuszczać, że ujrzymy w ten sposób nie naukę w działaniu, lecz naukę w gotowej postaci. Aby zilustrować to rozróżnienie, które wprowadził Latour w książce Science in Action ${ }^{14}$, posłużmy się prostym przykładem. Gdy studenci fizyki powtarzają jakiś klasyczny eksperyment, to służy to jedynie ich wyedukowaniu. Niepowodzenie w replikacji nie będzie ani dla studenta, ani dla prowadzącego podstawą do kwestionowania oryginalnych badań: niepowodzenie replikacji to konsekwencja niekompetencji studenta, kropka. Ale jeżeli jesteśmy w fazie ustalania tego, co jest faktem, a co nie, gdy pewne laboratoria starają się potwierdzić wyniki eksperymentalne innych pracowni, nie będzie już jasne to, czym tłumaczyć niepowodzenie replikacji: niekompetencją replikujących, kiepską komunikacją między zespołami, czy

13 B. Latour, Dajcie mi laboratorium, a poruszę świat, przeł. K. Abriszewski, Ł. Afeltowicz, „Teksty Drugie" 2009, nr 1-2, s. 163-192.

14 B. Latour, Science in Action: How to Follow Scientists and Engineers Through Society, Harvard University Press, Harvard 1987. 
błędami w oryginalnych badaniach. Rozstrzyganie tego typu dylematów nie jest łatwe, co dobrze udokumentowali socjologowie wiedzy naukowej z Bath ${ }^{15}$.

Zastanówmy się jednak, co by się stało, gdyby tego typu kontrowersje były publicznie dyskutowane. Transparentność laboratoriów raczej napędzałaby kryzys nauki, niż mu zapobiegała. Proszę rozważyć prosty przykład: podjętą w 2015 roku przez grupę Open Science Collaboration próbę powtórzenia stu eksperymentów psychologicznych opublikowanych w 2008 roku w renomowanych czasopismach psychologicznych ${ }^{16}$. Wyniki możemy odczytywać różnie: niektórzy zobaczą szklankę w połowie pustą (bo wielu doświadczeń nie udało się powtórzyć lub wyniki nie były identyczne), inni w połowie pełną (bo wiele udało się powtórzyć). Osobiście przyjąłem wyniki projektu z zainteresowaniem, gdyż poszerza on nasze rozumienie o samej replikacji eksperymentalnej i pcha nauki behawioralne do przodu. Jestem jednak socjologiem i badaczem rozumiejącym, w czym tkwi trudność replikacji. A jak rezultaty odbierze laik? Odczytanie wyników projektu jako powodu, by „wyrzucić psychologię eksperymentalną do kosza", wydaje się jedną z prawdopodobnych opcji. I tak właśnie zareagowało wielu publicystów.

Naukowcy zdają sobie sprawę, że brak transparentności działa na ich korzyść, a gra toczy się o autorytet: ich własny, ich zespołu, dyscypliny lub badań naukowych w ogóle. Świadomi byli tego na pewno badacze próbujący potwierdzić istnienie promieniowania grawitacyjnego, co osobiście obserwował i udokumentował Harry Collins ${ }^{17}$. Zanim uzyskano pierwszy sygnał potwierdzający istnienie fal - na który nota bene czekano latami - wywołano dwie sytuacje, które miały rozstrzygnąć, czy ogromny zespół, jaki pracował nad projektem, jest w stanie niezawodnie odróżnić autentyczny sygnał od „podróbki”. Zespół zdał test, choć rozstrzyganie problemu zajęło fizykom w pierwszym wypadku sześć, a w drugim przypadku trzy miesiące. Prowokacje były potrzebne, gdyż naukowcy musieli mieć pewność, że - gdy już ogłoszą swoje odkrycie - nie podniosą fałszywego alarmu, co mogłoby skutkować odcięciem finansowania dla tego wieloletniego i niezwykle kosztownego przedsięwzięcia.

PU: Rozwijając ustalenia Becka, mógłbym zapytać odwrotnie: czy taki obraz nauki nie jest pokłosiem tego, jak mało wiemy na temat zastosowań nauki w życiu codziennym? Według niektórych badaczy nauki, na przykład Stevena Shapina ${ }^{18}$, problem pojawia się w momencie, w którym nauka staje się niewidoczna (lub świadomie ukrywana), ponieważ rodzą się wtedy problemy z jej nieetycznym zastosowaniem

15 H. Collins, T. Pinch, Golem, czyli co trzeba wiedzieć o nauce, przeł. A. Tanalska-Dulęba, CiS, Warszawa 1998.

16 Open Science Collaboration, Estimating the Reproducibility of Psychological Science, „Science” 2015, t. 349 , nr 6251, aac4716.

17 H. Collins, Gravity's Kiss: The Detection of Gravitational Waves, The MIT Press, Cambridge, MA 2017.

18 S. Shapin, Invisible Science, „The Hedgehog Review” 2016, t. 18, nr 3, dostępny online: http://www. iasc-culture.org/THR/THR_article_2016_Fall_Shapin.php (dostęp: 1.03.2018). 
(na przykład w biznesie, ale także przez władzę). Czy rozpoznaje to pan jako problem? Jeśli tak, jak temu zaradzić?

ŁA: W tym przypadku nie ma konieczności odwoływania się do badań nad nauką: wystarczy dość elementarna wiedza na temat mechanizmów kontroli społecznej. Gdy nikt nie patrzy nam na ręce (lub myślimy, że tak jest), zachowujemy się inaczej. Pod nieobecność zewnętrznego nadzoru pozostaje liczyć na etos. Naukowcy mają bardzo szczególny etos, który - jak staraliśmy się przekonać razem z Radosławem Sojakiem $^{19}$, a idąc tropem wyznaczonym przez Shapina ${ }^{20}$ - łączy w sobie elementy kultury dżentelmenów oraz rzemieślników. Trudno jednak o etosowość w dobie dość silnej prekariatyzacji środowiska naukowego.

PU: Tym, czego się nie wie, też trzeba umiejętnie zarządzać - twierdzą niektórzy badacze skupieni wokół problemów komunikacji w nauce ${ }^{21}$. Wszelkie luki wiedzy są szczególnie cenne z punktu widzenia mediów, stanowią bowiem zaprzeczenie popularnego obrazu nauki jako wszechwiedzącej oraz dają możliwość spekulacji, która może wpływać na masową wyobraźnię i rodzić paranoiczne scenariusze. Jako przykład można podać nazwanie bozonu Higgsa mianem boskiej cząstki przez Leona Ledermana $^{22}$. To, wydawałoby się, niewinne porównanie weszło do powszechnego słownika i zaczęło prowokować do metafizycznych rozważań o funkcji nauki i radykalnych interpretacji działania samego Wielkiego Zderzacza Hadronów. Chciałbym w tym kontekście zapytać o sposoby popularyzacji wiedzy naukowej. Czy da się unikać sprzeczności, które potem uruchamiają wyobraźnię odbiorców takich przekazów?

ŁA: Każda osoba, która usiłuje coś zakomunikować, staje przed wyborem: (a) kontrolować treść komunikatu, w jakiś sposób go usztywnić, ale ograniczyć jego zasięg (na przykład do grona kilku specjalistów na świecie), czy (b) nastawić się na szeroki zasięg, ale pogodzić się z utratą kontroli. Decydując się na drugą strategię możemy mieć pewność, że komunikat zostanie jakoś przekłamany, strywializowany, przeinaczony, zawłaszczony lub - uogólniając w języku teorii aktora-sieci - przetłumaczony. Jak zauważył John Law, każdy przekład jest również - w różnym stopniu,

19 Ł. Afeltowicz, R. Sojak, Arystokraci i rzemieślnicy. Synergia stylów badawczych, Wydawnictwo Naukowe UMK, Toruń 2015.

20 S. Shapin, A Social History of Truth: Civility and Science in Seventeenth-century England, University of Chicago Press, Chicago 1994.

21 Mam tu na myśli szczególnie rozwijający się w ostatnich latach nurt sociology of scientific ignorance, który bada funkcję naukowej ignorancji. Zob. np. M. Gross, Ignorance and Surprise: Science, Society, and Ecological Design, The MIT Press, Cambridge 2010.

22 L. Lederman, The God Particle: If the Universe Is the Answer, What Is the Question?, Dell Publishing, New York 1993. 
ale jednak - zdradą ${ }^{23}$. Gdy wychodzimy poza wąskie grono specjalistów nie sposób uniknąc translacji przekazu naukowego i wykorzystywania ewentualnych luk. Można je korygować, ale pod warunkiem, że będziemy mieli do czynienia z sytuacją dialogu, a nie jednostronnej, autorytarnej komunikacji. Nie do tego jednak byli socjalizowani naukowi eksperci przez długie dziesięciolecia, przyzwyczajeni, że to odbiorca musi się dostosować. Oczywiście sytuacja się zmienia, czego przejawem jest między innymi rozwój partycypacyjnych form zarządzania kontrowersjami społecznymi wokół technologii.

PU: Jak odnosi się pan do kultury popularnej, która bierze na warsztat odkrycia naukowe? Czy dostrzega pan więcej pożytku czy szkód, jakie kultura popularna wyrządza obrazowi nauki?

ŁA: W tym przypadku możemy albo odnieść się do jakichś metaanaliz, ewentualnie powołać się na wyniki szeroko zakrojonych badań, albo skupić się na pojedynczych przypadkach i danych anegdotycznych. Raportów tego typu nie znam, a zamiast pracować w trybie studiów przypadku proponuję skupić się na pozytywnej dewiacji24 (czasami pisze się o pozytywnym odchyleniu). Tak określamy w socjologii zachowania odstające od normy, ale - wbrew potocznemu rozumieniu dewiacji - w jakiś sposób korzystne dla jednostki i wspólnoty, które czasami daje się upowszechnić w populacji. Pragnę tu wskazać dwa takie odchylenia, które pokazują, jak można wykorzystać kulturę popularną w budowaniu wizji nauki.

Pierwszy przykład to kanał YouTube Because Science ${ }^{25}$. Koncepcja jest prosta: prezenter (Kyle Hill) bierze na warsztat motywy kultury popularnej (głównie postacie i wydarzenia z uniwersów Gwiezdnych wojen, DC i Marvel, ale nie tylko) i wyjaśnia je w kategoriach fizyki, chemii, meteorologii, biologii etc. Czy miecz świetlny z Gwiezdnych wojen przeciąłby szpony Wolverine'a z uniwersum Marvela? Jak bardzo śmiertelna byłaby sztuczka Jokera z ołówkiem pokazana w Mrocznym Rycerzu Christophera Nolana? Jak tak naprawdę powinien wyglądać kosmos widziany z kabiny Sokoła Millennium zbliżającego się do prędkości światła? Czy scena ucieczki Magneto z więzienia zaprezentowana $\mathrm{z}$ filmie $X$-Men 2 jest realistyczna? Jak dużą mocą musiałby dysponować legendarny Kraken, by wciągnąć statek pod wodę bez łamania go na pół? To właśnie pytania, na które odpowiedzi uzyska geek, oglądając poszczególne filmy. Te nie są zbyt długie, zostały poprowadzone z humorem i mają ciekawą konwencję: materiały są w taki sposób montowane, że wydaje się, jakby prezenter rysował różnokolorowymi pisakami wizualizację w powietrzu, a następnie wchodził z nimi w fizyczne interakcje. Wszystko to sprawia, że wiedza naukowa prezentowana jest jako istotna, bo mająca związek z rzeczywistością i fascynująca

23 J. Law, Traduction/Trahison: Notes on ANT, „Convergencia” 2006, nr 13 (42), s. 47-72.

24 R. Pascale, J. Sternin, M. Sternin, The Power of Positive Deviance: How Unlikely Innovators Solve the World's Toughest Problems, Harvard Business Press, Boston 2010.

25 Zob. https://www.youtube.com/channel/UCvG04Y09q0HExnIjdgaqcDQ (dostęp: 16.11.2018). 
zarazem. Wniosek, który widz może wyciągnąć z wielu odcinków, jest taki, że świat widziany okiem naukowca bywa dużo bardziej spektakularny niż to, co zobaczymy w komiksach lub filmach. Nauka zna rzeczy, które nie śniły się scenarzystom Gwiezdnych wojen, twórcom postaci superbohaterów etc. Najlepsze jest w tym wszystkim to, że przekaz naukowy nie jest nachalny: to nie są filmiki edukacyjne, lecz po prostu dobra rozrywka adresowana do ludzi zorientowanych w konkretnej konwencji.

Można przemycać wiedzę naukową, ale można również promować samo uprawianie nauki. I tu drugie odchylenie. Fikcyjną postacią, która mocno przysłużyła się nauce, jest Indiana Jones: po premierze filmów z tym bohaterem wyraźnie wzrosła rekrutacja na studia archeologiczne ${ }^{26}$. Ciekawe, czy w podobny sposób wpłynęła na rekrutację na kierunki inżynieryjne i botanikę postać, w którą wcielił się Matt Damon w Marsjaninie? Być może swoistą rewolucję wywoła postać „księżniczki Disneya”, która niedawno gościła na srebrnym ekranie. Nie chodzi o bohaterkę jakiegoś filmu animowanego, lecz o Shuri, jedną z postaci z filmu Czarna Pantera (franczyza Marvel Cinematic Universe, której częścią jest film, to własność Walt Disney Studios). Postać ta promuje wizerunek ciemnoskórej kobiety zajmującej się zagadnieniami przyrodoznawczymi oraz techniczno-inżynieryjnymi, które znajdują swoje praktyczne konsekwencje (dodajmy, że w tym segmencie amerykańskiej nauki reprezentacja Afroamerykanek jest znikoma). Być może, analogicznie do Indiany Jonesa, postać ta wpłynie na wybory edukacyjne i zawodowe kobiet w różnym wieku ${ }^{27}$.

PU: Kwestia edukacji, która mogłaby być odpowiedzią na ignorancję, wydaje się bardzo ważna. Jest jednak o tyle problematyczna, że edukacja decentralizuje się pod wpływem rozszerzenia kanałów nowych mediów. Dodatkowo sprawę utrudnia fakt pewnego ograniczonego zrozumienia zawiłych treści - czy to fizyki, czy też socjologii, czy innych dyscyplin. Treści te mogą być po prostu postrzegane jako nieprzydatne, co nie zmienia faktu, że są ciągle konieczne do zrozumienia podstawowych procesów cywilizacyjnych (choćby znaczenia szczepionek). Pytanie składa się z dwóch pomniejszych: Jakich narzędzi edukacyjnych używać? I jak przy tym nie ignorować ignorancji?

ŁA: Zamiast odpowiadać na pytanie pozwolę sobie na pewną refleksję. Jako badacz żywo zainteresowany innowacjami - zarówno technologicznymi, jak i społecznymi - często pochylam się nad sytuacjami, gdy ludzie próbują rozwiązać jakieś palące kwestie (społeczne, polityczne, gospodarcze, zdrowotne etc.). Czasami ktoś wycho-

26 J. Berlin, How Indiana Jones Actually Changed Achaeology, „National Geographic”, 14.05.2015, https://news.nationalgeographic.com/2015/05/150514-indiana-jones-archaeology-exhibit-national-geographic-museum/ (dostęp: 16.11.2018).

27 W. Hickey, 'Black Panther'Is Groundbreaking, but It's Shuri Who Could Change the World, FiveThirtyEight, 16.02.2018, https://fivethirtyeight.com/features/black-panther-is-groundbreaking-but-itsshuri-who-could-change-the-world/ (dostęp: 16.11.2018). 
dzi z rozwiązaniem techno-solucjonistycznym ${ }^{28}$ : napiszmy aplikację na smartfona albo wygenerujmy jakąś tabletkę, która zmieni ludzkie zachowania lub zlikwiduje problem. Ktoś inny mówi językiem prawno-instytucjonalnym: potrzebujemy nowych regulacji lub sposobów ich egzekwowania. Ewentualnie pojawia się ktoś podkreślający konieczność głębokiej zmiany: musimy oddziaływać na kulturę i kształtować praktyki społeczne. Bardzo często jednak nawołuje się po prostu do edukowania i uświadamiania. Gdy debatę specjalistów skupioną wokół jakiegoś problemu dominują hasła typu „Edukacja przede wszystkim” lub podobne, jest to dla mnie sygnał ostrzegawczy, że najprawdopodobniej nikt nie ma dobrego pomysłu na rozwiązanie problemu lub może nikt tak naprawdę nie rozumie, na czym ten polega. Edukacja to najczęściej hasło-wytrych. Ponadto nawoływanie do edukowania to sygnał, że „mleko się rozlało": pewne negatywne zjawiska są już na tyle utrwalone, że pozostaje nam jedynie podejmowanie działań pozornych, które służą głównie podtrzymaniu naszego dobrego samopoczucia, łagodzeniu lęków lub zachowaniu pozytywnej autoidentyfikacji przez jakąś grupę bądź organizację.

Nie wiem, czy mamy rzeczywiście problem z zaufaniem do nauki. Jeżeli uznamy roboczo, że tak, to edukowanie nie jest najlepszą strategią, a już na pewno nie jedyną. Więcej, edukowanie może przynieść efekt odmienny od zamierzonego. Badania nad zwolennikami teorii spiskowych pokazują, że skonfrontowanie ich z poprawną wiedzą nie sprawia, że spadają im łuski z oczu. Wręcz przeciwnie: pojawia się reakcja obronna i okopują się oni jeszcze głębiej na swoich stanowiskach ${ }^{29}$.

28 E. Morozov, To Save Everything, Click Here: The Folly of Technological Solutionism, Public Affairs, New York 2013.

29 A. Bessi, M. Coletto, G. Davidescu, A. Scala, G. Caldarelli, W. Quattrociocchi, Science vs Conspiracy: Collective Narratives in the Age of Misinformation, „PLoS One” 2015, t. 10, nr 2, e0118093; F. Zollo, A. Bessi, M. Del Vicario, A. Scala, G. Caldarelli, L. Shekhtman, W. Quattrociocchi, Debunking in a World of Tribes, „PloS One” 2017, vol. 12, nr 7, e0181821. 